\title{
Binding affinities of hexahydro-difenidol and hexahydro-sila-difenidol analogues at four muscarinic receptor subtypes: constitutional and stereochemical aspects
}

\author{
Magaii Ẅaelbroeck ${ }^{1}$, Jean Camus ', Michèle Tastenoy ${ }^{1}$, Ernst Mutschler ${ }^{2}$, Carsten Strohmann ${ }^{3}$, \\ Reinhold Tacke ${ }^{3}$, Günter Lambrecht ${ }^{2}$ and Jean Christophe ${ }^{3}$ \\ 'Department of Biochemistry and Nutrition, Medical School, Free University of Brussels, B-J000 Brussels, Belgium; ' Department of Pharmacology; \\ University of Frankfurt, Theodor-Stern-Kai 7, Geb. 75A, D.6000 Frankfurı am Main, F.R.G; and 'Institute of Inorganic Chemistn;, \\ University of Karlsruhe, Engesserstrasse, Geb. 30.45, D-750n Karisruhe, F.RG.
}

Received 27 June 1990, revised ms received 2 October 1990, accepted 16 October 1990

Hexahydro-sila-difenidol and eight analogues behaved as simple competitive inhibitors of $\left[{ }^{3} \mathrm{H}\right] \mathrm{N}$-methyl-scopolamine binding to homogenates from human neuroblastoma NB-OK 1 cells $\left(M_{1}\right.$ sites), rat heart $\left(M_{2}\right.$ sites), rat pancreas $\left(M_{3}\right.$ sites), and rat striaturn ' $B$ ' sites $\left(M_{4}\right.$ sites). Pyrrolidino- and hexamethyleneimino analogues showed the same selectivity profile as the parent compound. Hexahydro-sila-difenidol methiodide and the methiodide of p-fluoro-hexahydro-sila-difenidol had a higher affinity but a lower selectivity than the tertiary amines. Compounds containing a p-methoxy, p-chloro or p-fluoro substituent in the phenyl ring of hexahydro-sila-difenidol showed a qualitatively similar selectivity profile as the parent compound (i.e., $M_{1}=M_{3}=M_{4}=M_{2}$ ), but up to 16-fold lower affinities. o-Methoxy-hexahydro-sila-difenidol has a lower affinity than hexahydro-sila-difenido! at the four binding sites. Its selectivity profile $\left(M_{4}>M_{1}, M_{3}>M_{2}\right)$ was different from hexahydro-sila-difenidol.

Replacement of the central silicon atom of hexahydro-sila-difenidol, p-fluoro-hexahydro-sila-difenidol and their quaternary (N-methylated) analogues by a carbon atom did not change their binding affinities significantly. The four muscarinic receptors showed a higher affinity for the (R)- than for the (S)-enantiomers of hexahydro-difenidol, p-lluorohexahydro-difenidol and their methiodides. The stereoselectivity varied depending on the receptor subtype and drug considered.

Muscarinic receptor subtypes $\left(M_{1}, M_{2}, M_{3}\right.$, and (putative) $\left.M_{4}\right)$; Muscarinic receptor antagonists (selective); Hexahydro-sila-difenidol analogues; p-Fluoro-hexahydro-sila-difenidol; Stereoselectivity (at muscariric receptors)

\section{Introduction}

Muscarinic acetylcholine receptors are currently divided into at least three pharmacologically defined subtypes: $\mathrm{M}_{1}, \mathrm{M}_{2}\left(\mathrm{M}_{2 \alpha}\right)$ and $\mathrm{M}_{3}\left(\mathrm{M}_{2 \beta}\right)$ receptors (for recent reviews, see Mutschler et al., 1987; 1988; Mitchelson, 1988; Levine and Birdsall, 1989). $M_{1}$ receptors are typically found in neuronal tissues (central nervous system and autonomic ganglia), $\mathrm{M}_{2}$ receptors in lower brain areas (cerebellum) and heart, and $\mathbf{M}_{3}$ receptors in secretory glands and smooth muscle. This classification is based mainly on the different affinities of muscarinic receptor subtypes for antagonists such as pirenzepine $\left(M_{1}>M_{3} \geqslant M_{2}\right)$ (Hammer et al., 1980; Eltze et al.. 1988; Waelbroeck et al., 1988), AF-DX 116 (Giachetti et al., 1986; Hammer et al., 1986; Micheletti et al., 1987), methoctramine (Melchiorre et al., 1987; Giraldo et al., 1988) $\left(M_{2}>M_{1}>M_{3}\right)$ and hexahydro

Correspondence to: Jean Christophe, Department of Biochemistry and Nutrition, Medical School, Free University of Brussels, Boulevard of Waterioo 115, B-1000 Brussels, Belgium. sila-difenidol (Lambrecht et al., 1987, 1989b; Waelbroeck et al., 1987a; Waelbroeck et al. 1989a; Lazareno and Roberts, 1989) $\left(M_{3} \geqslant M_{1}>M_{2}\right)$. Recently a fourth subtype with high affinity for methoctramine and himbacine. as well as for hexahydro-sila-difenidol and 4-diphenylacetoxy-N. methylpiperidine methiodide has been identified in NG108-15 cells (Michel et al., 1989) and rat forebrain (Waelbroeck et al., 1990). The antagonist binding properties, or the tissue and cell line distribution of these four pharmacologically defined subtypes correspond closely to that of the recently cloned receptor proteins ml to m4 (Akiba et al., 1988; Bonner et al., 1987; Peralta et al. 1987; Buckley et al., 1989; Dörje et al., 1990; Wess et al., in press).

Using the nonselective antagonist $\left[{ }^{3} \mathrm{H}\right] \mathrm{N}-$ methylscopolamine $\left.\left({ }^{3} \mathrm{H}\right] \mathrm{NMS}\right)$ as radioligand, we previously demonstrated that over $80 \%$ of the muscarinic receptors in the human neuroblastoma NB-OK 1 cell line are of the $M_{1}$ subtype (Waelbroeck et al., 1988), that receptors in rat heart are of the $M_{2}$ subtype (Waelbroeck et al., $1987 \mathrm{a}, \mathrm{b})$, receptors in rat pancreas belong to the $\mathrm{M}_{3}$ subtype (Waelbroeck et al., 1987a), and that $85 \%$ of the 
' $\mathrm{B}$ ' binding sites in rat striatum (Waelbroeck et al., $1987 \mathrm{~b}$ ) can be considered as putative $M_{4}$ receptors (Waelbroeck et al., 1990).

The first aim of the present study was to examine the binding properties of eight hexahydro-sila-difenidol analogues structurally modified in the cyclic amino group and the phenyl ring (fig. 1). using the four above-mentioned test systems. The functional antimuscarinic properties of these muscarinic antagonists have been reported recently (Lambrecht et al., 1989a.b; Waelbroeck et al., 1989a). All these silicon compounds possess a center of chirality. They were used as racemates since indications were found that silanols $\left(\mathrm{R}_{3} \mathrm{SiOH}\right)$ may racemize in aqueous solution (Tacke et al., 1987). The second goal of this study was to investigate the importance of absolute configuration for binding of bexahydro-sila-difenidol analogues to muscarinic receptors. To achieve this goal we used the configurationally stable (R)- and (S)-enantiomers of the four carbon analogues of $1 \mathrm{~b}, 4 \mathrm{~b}, 8 \mathrm{~b}$ and $9 \mathrm{~b}(\rightarrow$ compounds 1a. 4a, 8a and 9a, Fig. 1). The functional antimuscarinic properties of the (R)- and (S)-enantiomers of hexahydro-difenidol (1a), p-fluoro-hexahydro-difenidol (8a) and their methiodides $4 a$ and $9 a$ have been reported elsewhere (Tacke et al., 1989; Feifel et al., 1990; Lambrecht et al., 1990).

\section{Materials and methods}

\subsection{Cell and tissue preparation:}

Human NB-OK 1 neuroblastoma cells (a generous gift from Dr. Yanaihara, Shizuoka, Japan) were maintained in RPMI-1640 medium, enriched with $100 \mathrm{U} / \mathrm{ml}$ penicillin, $100 \mu \mathrm{g} / \mathrm{ml}$ streptomycin and $10 \%$ fetal calf serum (from Gibco, Gent, Belgium). Twice a week, the cells were detached by trypsin-EDTA (Gibco, Gent, Belgium) and divided in thirds. For $\left[{ }^{3} \mathrm{H}\right] \mathrm{NMS}$ binding experiments, the cells were harvested using a $20 \mathrm{mM}$ sodium phosphate buffer enriched with $1 \mathrm{mM}$ EDTA

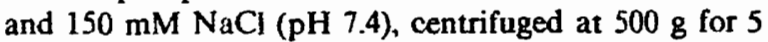
min, resuspended and homogenized in $20 \mathrm{mM}$ Tris- $\mathrm{HCl}$ buffer enriched with $5 \mathrm{mM} \mathrm{MgCl}{ }_{2}(\mathrm{pH} \mathrm{7.5)}$ in a glassTeflon homogenizer, and then stored in liquid nitrogen until use.

For cardiac homogenates, male Wistar albino rats $(200-250 \mathrm{~g})$ were decapitated, the heart immediately removed and rinsed in $150 \mathrm{mM} \mathrm{NaCl}$. The homogenization buffer contained $20 \mathrm{mM}$ Tris-HCl (pH 7.5) and 250 $\mathrm{mM}$ sucrose. Each heart was homogenized in $2 \mathrm{ml}$ of this buffer with an Ultraturrax homogenizer (maximal speed for $5 \mathrm{~s}$ at $4^{\circ} \mathrm{C}$ ) followed by further addition of 13 $\mathrm{ml}$ of buffer, and seven up and down strokes in a

\begin{tabular}{|c|c|c|c|c|}
\hline Formula & No. & El & $\mathbf{R}$ & $n$ \\
\hline \multirow{9}{*}{ ( } & $(R)-$ and $(S)-1$ 旦 & $\mathrm{C}$ & $\mathrm{H}$ & 5 \\
\hline & $(\mathrm{R} / \mathrm{S})-1 \mathrm{~b}$ & Si & $\mathbf{H}$ & 5 \\
\hline & $(R / S)-\underline{2}$ & Si & $\mathbf{H}$ & 4 \\
\hline & $(R / S)-\underline{3}$ & $\mathrm{Si}$ & $\mathbf{H}$ & 6 \\
\hline & $(R / S)-\underline{5}$ & $S i$ & p. $\mathrm{CH}_{3} \mathrm{O}$ & 5 \\
\hline & $(R / S)-6$ & Si & $0 . \mathrm{CH}_{3} \mathrm{O}$ & 5 \\
\hline & $(\mathrm{R} / \mathrm{S})-7$ & St & $\mathrm{p}-\mathrm{Cl}$ & 5 \\
\hline & $(R)-$ and $(S)-8$ a & $\mathrm{C}$ & $p-F$ & 5 \\
\hline & $(R / S)-\underline{8 b}$ & Sì & $p-F$ & 5 \\
\hline \multirow[t]{5}{*}{ Formula } & No. & El & $\mathbf{R}$ & \\
\hline & $(R)$ and $(S)-4$ a & C & $\mathrm{H}$ & \\
\hline & $(R / S)-\underline{4} \underline{b}$ & Si & $\mathrm{H}$ & \\
\hline & $(R)-$ and $(S)-9$ a & c & $\mathrm{F}$ & \\
\hline & $(R / S)-9 b$ & $\mathbf{S i}$ & $\mathbf{F}$ & \\
\hline
\end{tabular}

Fig. 1. Chemical structure of the carbon/silicon analogues, hexahydro-difenidol (1a), hexahydro-sila-difenidol (1b) and their derivatives (2), (3), hexahydro-difendol methiodide (4a), hexahydro-sila-difenidol methiodide (4b), p-methoxy-hexahydro-sila-difenidol (5), o-methoxy-hexahydrosila-difenidol (6), p-chloro-her hvdro-stn-öfciüil (7); p-fluoro-hexahydro-difenidol (8a), p-fluorohexahydro-sila-difenidol (8b), p-fluoro-hexabydro-difew jol methiodide $(9 a)$ and p-fluoro-hexahydro-sila-difenidol methiodide $(9 b)$. 
glass-Teflon homogenizer (at $4^{\circ} \mathrm{C}$ ). The homogenate was filtered on two layers of medical gauze and either used fresh, or stored in liquid nitrogen until use.

For rat brain cortex and striatum homogenates the brain was immediately removed and dissected. The cortex and striatum were homogenized in 15 and $2 \mathrm{ml}$, respectively: of $20 \mathrm{mM}$ Tris- $\mathrm{HCl}$ buffer $(\mathrm{pH} \mathrm{7.5)} \mathrm{en-}$ riched with $250 \mathrm{mM}$ sucrose, with a glass-Teflon homogenizer, and stored in liquid nitrogen until use. These homogenates were diluted 20 -fold with the homogenization buffer before use for ${ }^{3} \mathrm{H}$ ]NMS binding experiments.

For rat pancreas homogenates the organ was immediately removed, minced with scissors and homogenized in a glass-Teflon homogenizer (seven uo and down strokes at $4^{\circ} \mathrm{C}$ ) in a solution containing $300 \mathrm{mM}$ sucrose, $0.2 \mathrm{mg} / \mathrm{ml}$ bacitracin and $500 \mathrm{kallikrein}$ inhibitor $\mathrm{U} / \mathrm{ml}$ of Trasylol (Bayer, Brussels, Belgium). The resulting homogenate was immediately filtered on two layers of medical gauze and diluted 11-fold with the incubation buffer made of $66 \mathrm{mM}$ sodium phosphate ( $\mathrm{pH}$ 7.4) enriched with $2.6 \mathrm{mM} \mathrm{MgCl}_{2}, 500$ kallikrein inhibitor $\mathrm{U} / \mathrm{ml}$ of Trasylol, $0.2 \mathrm{mg} / \mathrm{ml}$ hacitracin and $13 \mathrm{mg} / \mathrm{ml}$ bovine serum albumin.

\section{2. $\left[^{3} H\right] N M S$ binding experiments}

$\left[^{3} \mathrm{H}\right]$ NMS binding was measured at $25^{\circ} \mathrm{C}$ in a total volume of $1.2 \mathrm{ml}$ using the following incubation buffer: $50 \mathrm{mM}$ sodium phosphate ( $\mathrm{pH} 7.4$ ) enriched with $2 \mathrm{mM}$ $\mathrm{MgCl}_{2}, 1 \%$ bovine serum albumin (except when indicated) and the indicated tracer and drug concentrations. Addition of bovine serum albumin to the incubation buffer increased $\left[^{3} \mathrm{H}\right.$ ]NMS binding very slightly (by at most 10-15\%) and improved the reproducibility of duplicates in our filtration assays. In binding experiments on pancreas homogenates, we also added Trasylol and bacitracin (see above) to further inhibit proteolytic activity. Bovine serum albumin was an essential ingredient in pancreas binding studies, since the binding capacity of pancreas homogenates disappeared within $40 \mathrm{~min}$ at room temperature if this protein was omitted from the buffer, but was maintained over $90 \%$ for at least $4 \mathrm{~h}$ in its presence.

To terminate the incubation, each sample was diluted with $2 \mathrm{ml}$ of ice-cold $50 \mathrm{mM}$ sodium phosphate buffer (pH 7.4) and filtered on GF/C glass-fiber filters (Whatman, Maidstone, England) presoaked in $0.05 \%$ polyethyleneimine. The filters were rinsed three times with the same filtration buffer, dried, and the radioactivity (bound nacer) counted by liquid scintillation. Nonspecific binding was defined as $\left[{ }^{3} \mathrm{H}\right] \mathrm{NMS}$ binding in the presence of $1 \mu \mathrm{M}$ atropine in the four systems.

For $\left[{ }^{3} \mathrm{H}\right] \mathrm{NMS}$ binding to human NB-OK 1 cell ho- mogenates, a $0.25 \mathrm{nM}$ tracer concentration (twofold $\mathrm{K}_{\mathrm{D}}$ in this system) was chosen with a homogenate concentration of $160-200 \mu \mathrm{g}$ protein per assay (about 50 $\mathrm{pM}$ binding sites) and an incubation period of $2 \mathrm{~h}$ at $25^{\circ} \mathrm{C}$ allowing full equilibration of tracer binding.

In binding experiments on rat cardiac homogenates, a $1 \mathrm{nM}$ [ $\left.^{3}: 1\right] N M S$ concentration (two-fold $K_{D}$ in this system) was selected with a homogenate concentration of $400-500 \mu \mathrm{g}$ protein per assay (about $250 \mathrm{pM}$ binding sites) and a $2 \mathrm{~h}$ incuba:ion period at $25^{\circ} \mathrm{C}$ allowing full equilibration of tracer binding-

In binding experiments on rat cortex or striatum homogenates, the tracer concentration was $0.25 \mathrm{nM}$ and the protein concentration $30-40 \mu \mathrm{g}$ per assay (about 50 pM binding sites). Under equilibrium conditions ( $2 \mathrm{~h}$ incubation at $25^{\circ} \mathrm{C}$,,$\left[^{3} \mathrm{H}\right] \mathrm{NMS}$ labelled $\mathrm{M}_{3}, \mathrm{M}_{3}$ and $\mathrm{M}_{4}$ sites in these two brain regions. In order to analyze tracer binding to brain $\mathrm{M}_{4}$ sites only, we chose the striatum, which possesses fewer $M_{1}$ and $M_{3}$ receptors than other forebrain areas (Waelbroeck et al., 1990). We preincubated striatum homogenates for $2 \mathrm{~h}$ at $25^{\circ} \mathrm{C}$ to allow equilibrium binding, then induced tracer dissociation by adding $1 \mu \mathrm{M}$ atropine. ${ }^{3} \mathrm{H}$ NMS dissociated from its binding sites after $35 \mathrm{~min}$ of isotopic dilution, the residual binding being about $30 \%$ of initial binding. Since [ ${ }^{3} \mathrm{HINMS}$ dissociation from $\mathrm{M}_{3}$ sites is faster than that from $M_{3}$ and $M_{4}$ sites, $85 \%$ of this residual $\left.{ }^{3} \mathrm{H}\right]$ NMS binding corresponded to $M_{4}$ binding sites. It is necessary to keep tracer binding below $15 \%$ of the total tracer added to avoid distorsions of the competition curves due to tracer or unlabelled drug depletion. This means that tracer binding to striatum $\mathbf{M}_{4}$ sites in the absence of unlabelled drug must be maintained below $5 \%$ of the total tracer added (i.e., $30 \%$ of the $15 \%$ initial binding). We therefore decided to use a comparatively high $\left.{ }^{3} \mathrm{H}\right] \mathrm{NMS}$ concentration $(0.25 \mathrm{nM}$, equivalent to five-fold $\mathrm{K}_{\mathrm{D}}$ at $\mathrm{M}_{4}$ sites) for these experiments.

In binding experiments on rat pancreas homogenates we used $980 \mu l$ of the homogenate per $1.2 \mathrm{ml}$ sample. The $\left[{ }^{3} \mathrm{H}\right] \mathrm{NMS}$ concentration was $0.25 \mathrm{nM}$ (two-fold $\mathrm{K}_{\mathrm{D}}$ in this system) and protein concentration $800-1000 \mu \mathrm{g}$ per assay (about $50 \mathrm{pM}$ binding sites). An incubation period of $4 \mathrm{~h}$ was necessary to allow binding equilibrium.

Protein concentration was measured according to Lowry et al. (1951) using bovine serum albumin as standard.

\subsection{Dara anal:sis and statistics}

The competition curves were analyzed using the computer program described by Richardson and Humrich (1984), and were compatible with the existence of a single receptor type. $K_{\text {, values were calculated from }}$ $I_{\text {so }}$ values using the Cheng and Prusoff (1973) equa- 
tion. The $\mathrm{pK}_{\mathrm{i}}$ value was defined as $-\log \mathrm{K}_{\mathrm{i}}$. Each experiment was repeated at least three times. The standard deviations of each $1 \mathrm{C}_{50}$ value was below $30 \%$ of the average value in all cases (corresponding to $\mathrm{pK}$, standard deviations of $<0.1 \log$ unit) and were therefore not mentioned in the tables and figures. The data are presented as means of the indicated number of experiments.

\subsection{Drugs and chemicals}

$\left[{ }^{3} \mathrm{H}\right] \mathrm{NMS}$ (74 $\left.\mathrm{Ci} / \mathrm{mmole}\right)$ was obtained from Amersham International (Bucks, England). Atropine, polyethyleneimine and bovine serum albumin (Cohn fraction V) were obtained from Sigma Chemical Co. (St. Louis, MO, U.S.A.). Tissue culture material and media were obtained from Gibco (Gent. Belgium). All other chemicals were of the highest grade available.

Hexahydro-sila-difenidol ( $1 \mathrm{~b}$ ) and the analogues shown in fig. 1 were synthesized in our laboratories ((R)- and (S)-1a: Tacke et al., 1989; 1b: Tacke et al., 1985; 4b: Waelbroeck et al., 1989a; 2, 3, 5, 6. 7 and 8b were prepared by analogy to the synthesis of $1 \mathrm{~b}$, unpublished results; (R)- and (S)-8a were prepared by analcgy to the synthesis of (R)- and (S)-1a, unpublished results; the quaternary ammonium compounds (R)- and (S)-4a, (R)- and (S)-9a as well as $9 \mathrm{~b}$ were prepared by quaternization of the corresponding free amines with methyl iodide analogous to the synthesis of $4 \mathrm{~b}$. unpublished results). The enantiomeric purity of the enantiomers of la, 4a. Sa and 9a was $>99.7 \%$ as determined on the basis of calorimetric analyses (differential scanning calorimetry) of (R)- and (S)-1a (Tacke et al., 1989) and (R)- and (S)-8a (unpublished results). The experimental procedure (Sarge and Cammenga, 1985; Tacke et al., 198 i, 1989) and data evaluation (Sarge et al., 1988) followed the lines described in the literature.

\section{Results}

\section{J. General considerations}

All the competition curves obtained in this study were compatible with the existence of a single receptor subtype in the different preparations with Hill coefficients not significantly different from unity $\left(\mathbf{n}_{\mathrm{H}}\right.$ varied between 0.95 and 1.10 , with standard deviations below or equal to 0.05 ). This suggested that $l^{3}$ HINMS labelled in each of the tissues homogeneous binding sites which was not discriminated by the drugs used.

Competition curves with p-chloro-hexahydro-sila-difenidol (7) were shifted to the right by 0.5 to $1.0 \mathrm{log}$ units in all systems in the presence of bovine serum albumin (1\%). This is illustrated in fig. 2 using cortex homogenates. Almost 10-fold higher concentrations of 7 were needed to inhibit $\left[{ }^{3} \mathrm{H}\right] \mathrm{NMS}$ binding in this tissue when 'fraction $\mathrm{V}$ ' bovine serum albumin was added to

TABLE 1

Antagonist affinities (pK, values) ${ }^{\circ}$ of hexahydro-sila-difenidol (lb) and analogues $1 \mathrm{a}, 2,3,4 \mathrm{a}, 4 \mathrm{~b}, 5-7,8 \mathrm{a}, 8 \mathrm{~b} .9 \mathrm{a}$ and $9 \mathrm{~b}$ obtained in binding studies on homogenates of human NB-OK 1 cells $\left(M_{1}\right.$ receptors) as well as rat hearl ( $M_{2}$ receptors), pancreas ( $M_{3}$ receptors) and striatum ( $M_{4}$ receptors) in the presence or absence of $1 \%$ bovine serum albumin.

\begin{tabular}{|c|c|c|c|c|}
\hline Antagonist & Human NB-OK 1 & Rat heart & Rat pancreas & Rat striatum $\mathbf{M}_{\mathbf{4}}$ \\
\hline (R)-1a hexahydro-difenidol & 8.2 & 7.0 & 8.1 & 7.9 \\
\hline (S)-la hexahydro-difenidol & 6.1 & 5.8 & 5.9 & 6.0 \\
\hline Ib hexahydro-sila-difenidol ${ }^{b}$ & 7.8 & 6.7 & 7.8 & 7.9 \\
\hline 2 pyrrolidino analogue of hexahydro-sila-difenidol & 8.2 & 0.9 & 7.8 & 7.9 \\
\hline 3 hexamethyleneimino analogue of hexahydro-sila-difenidol & 7.3 & 6.4 & 7.1 & 7.4 \\
\hline (R)-4a hexahydro-difenidol methiodide & 8.6 & 8.2 & 8.1 & 8.5 \\
\hline (S)-4a hexahydro-difenidol methiodide & 6.5 & 6.0 & 5.5 & 6.1 \\
\hline $4 \mathrm{~b}$ hexahydro-sila-difenidol methiodide ${ }^{\circ}$ & 8.8 & 8.0 & 8.2 & 8.6 \\
\hline 5 p-methoxy-hexahydro-sila-difenidol & 6.7 & 5.8 & 7.0 & 6.7 \\
\hline 60 -methoxy-hexahydro-sila-difenidol & 6.6 & 6.1 & 6.5 & 7.0 \\
\hline 7 p-chloro-hexahydro-sila-difenidol & 7.6 & 6.1 & $7.6^{\mathrm{d}}$ & 7.6 \\
\hline (R)-8a p-fluoro-hexahydro-difenidol ${ }^{c}$ & 7.9 & 6.7 & - & 7.9 \\
\hline (S)-8a p-fluoro-hexahydro-difenidol c & 5.9 & 5.6 & - & 5.8 \\
\hline 8b p-nuoro-hexahydro-sila-difenidel c & 7.8 & 6.5 & 7.8 & $7.8^{d}$ \\
\hline (R)-9a p-fluoro-hexahydro-difenidol methiodide c & 8.4 & 7.8 & - & 8.2 \\
\hline (S)-9a p-fluoro-hexahydro-difenidol methiodide c & 6.3 & 5.9 & - & 6.2 \\
\hline 9b p-fluoro-hexahydro-sila-difenidol methiodide ${ }^{c}$ & 8.3 & 7.6 & - & 8.3 \\
\hline
\end{tabular}

pK values $\left(-\log \mathrm{K}_{1}\right)$ were measured by competition with $\left[{ }^{3} \mathrm{H}\right.$ ) NMS binding, as explained in Materials and methods. The numbers show the mean estimate for three experiments. The S.D. was approximately $0.1 \mathrm{log}$ unit.

${ }^{b} \mathrm{pK}_{i}$ values for $1 \mathrm{~b}$ and $4 \mathrm{~b}$ in membranes from NB-OK 1 cells, rat hear and rat pancreas were previously published (Waelbroeck et al., $1989 \mathrm{a}$ ) $\mathrm{pK}_{\mathrm{i}}$ values measured in the absence of bovine serum albumin (see text).

The competition curves obtained in the presence of bovine serum albumin in pancreas and NB-OK 1 homogenates were superimposable, suggesting that compounds 7 and $8 b$ had the same affinity for $M_{3}$ as for $M_{1}$ receptors. 


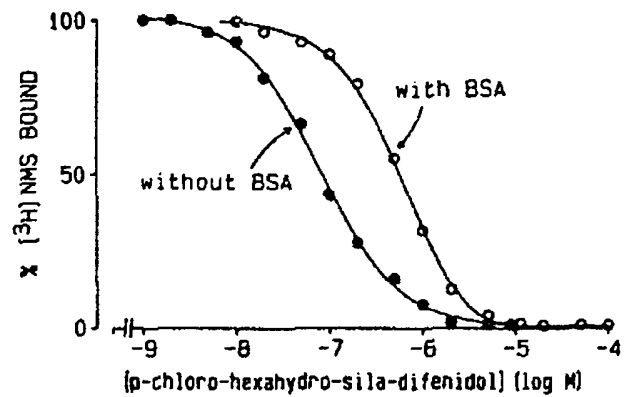

Fig. 2. p-Chloro-hexahydro-sila-difenidol (7)- $\left.{ }^{3} \mathrm{H}\right] \mathrm{NMS}$ competition curves in rat brain cortex homogenates, in the absence $(\bullet)$ or presence (O) of 19 BSA (Cohn fraction $V$ ) in the incubation buffer. One experiment is representative of three performed in duplicate.

the incubation buffer. This suggested that about $90 \%$ of compound 7 was bound to bovine serum albumin or a contaminant. Similar results were obtained with p-fluoro-hexahydro-sila-difenidol ( $8 b)$ and its methiodide (9b) and with the (R)-enanticmers of the corresponding carbon analogues $8 \mathrm{a}$ and $9 \mathrm{a}$. We therefore determined the binding affinities of compounds $7,8 \mathrm{a}, 8 \mathrm{~b}, 9 \mathrm{a}$ and $9 \mathrm{~b}$ (Fig. 1) to muscarinic receptors in homogenates from human NB-OK 1 cells, rat heart and striatum in the absence of bovine serum albumin. $\mathrm{pK}_{\mathrm{i}}$ values are given in table 1.

The binding properties of hexahydro-difenidol (1a), hexahydro-sila-difenidol (1b) and their analogues 2, 3, $4 a, 4 b, 5$ and 6 (fig. 1) were hardly affected by inclusion of bovine albumin into the incubation buffer $\left(\mathrm{pK}_{\mathrm{i}}\right.$ increase below $0.3 \mathrm{log}$ units). This allowed us to perform binding experiments with these compounds in all tissues in the presence of bovine serum albumin (table 1).

\subsection{Structural variations of the amino group}

A comparison of binding affinities of ( $R$ )-hexahydro-difenidol ((R)-1a), hexahydro-sila-difenidol (1b) and compounds $2 / 3$ and $4 a / 4 b$ as well as $8 a / 9 a$ and $8 b / 9 b$ outlined the effect of structural variations of the cyclic amino (ammonium) group on antimuscarinic potency (table 1). Increasing the size of the amino group from pyrrolidino to piperidino $(2 \rightarrow 1 b)$ decreased the affinity for $M_{1}$ and (to a lesser extent) $M_{2}$ sites. Ex. change of the piperidino by the hexamethyleneimino group $(1 b \rightarrow 3)$ decreased the affinities for the four binding sites. N-Methylation of the silicon compounds $1 \mathrm{~b}$ and $8 \mathrm{~b}(\rightarrow 4 \mathrm{~b}$ and $9 \mathrm{~b})$ increased the affinity for the four binding sites, this increase being greatest at $M_{2}$ receptors. This $\mathrm{N}$-methylation effect on the affinity of the silicon compounds $1 \mathrm{~b}$ and $8 \mathrm{~b}$ was comparable to or greater than the affinity increase observed with the corresponding $(R)$-configurated carbon analogues $(R)-1$ a $(\rightarrow(R)-4 a)$ and $(K)-8 a(\rightarrow(R)-9 a)$.

\subsection{Substitutions on the phenyl ring}

The influence of substituents in the phenyl ring of hexahydro-sila-difenidol (1b) on binding affinity can be demonstrated by comparison of the silicon compounds $1 b, 5,6,7$ and $8 b$. as well as compounds $4 b$ and $9 b$ (table 1). Introduction of a methoxy substituent in para or ortho position (compounds 5 and 6 ) or a p-chloro substituent (7) reduced the affinity to the muscarinic receptors up to 16-fold (table 1). The influence of a fluoro substituent in para position of hexahydro-siladifenidol $(1 b \rightarrow 8 b)$ and its methiodide $(4 b \rightarrow 9 b)$ on affinity was moderate.

\subsection{Sila substitution}

It was not possible to determine exactly the effect of sila substitution on the binding properties of the carbon compounds 1a, $4 a, 8 a$ and $9 a$ from the present results. We did indeed use the pure enantiomers of $1 \mathrm{a}, 4 \mathrm{a}, 8 \mathrm{a}$ and $9 \mathrm{a}$ in this study but investigated the binding affinities of the racemic mixtures $(R / S)$ of the silicon analogues $1 \mathrm{~b}, 4 \mathrm{~b}, 8 \mathrm{~b}$ and $9 \mathrm{~b}$ (see introduction). The $\mathrm{pK}_{\mathrm{i}}$ values (table 1 ) of racemic $1 b, 4 b, 8 b$ and $9 b$ may therefore be lower by at most $0.3 \log$ unit than the $\mathrm{pK}_{i}$ values of their high-affinity enantiomers. This is due to the presence of $50 \%$ of the low-affinity enantiomers in the binding assay. If this is taken into account, it is obvious from table 1 that sud-substitution did not significantly affect the binding properties of $1 \mathrm{a}, 4 \mathrm{a}, 8 \mathrm{a}$ and $9 \mathrm{a}$ at any subtype.

\subsection{Stereoselectivity}

The effect of $N$-methylation of (R)- and (S)-hexahydro-difenidol ((R)- and (S)-1a; $\rightarrow$ (R)- and (S)-4a) and (R)- and (S)-p-fluoro-hexahydro-difenidol ((R)- and (S)-8a; $\rightarrow$ (R)- and (S)-9a) on the affinity for the muscarinic receptor depended on the receptor subtype and on the configuration of the drug (table 2). In NB-OK 1 cells $\left(M_{1}\right.$ sites), the affinity of both enanti-

\section{TABLE 2}

Stereoselectivity ((R)/(S)) ratios at muscarinic receptor subtypes. The values shown represent the antilogs of the differences between corresponding mean $\mathrm{pK}$, values of the ( $\mathrm{R})$ and $(\mathrm{S})$-enantiomers (table 1$)$ determined at $M_{1}$ receptors in NB-OK 1 cells, $M_{2}$ receptors in rat heart, as well as $M_{3}$ and $M_{4}$ receptors in rat pancreas and strialum.

\begin{tabular}{lrrrr}
\hline & \multicolumn{4}{c}{ Siereoselectivity ratios } \\
\cline { 2 - 5 } & $\mathrm{M}_{3}$ & $\mathrm{M}_{2}$ & $\mathrm{M}_{3}$ & $\mathrm{M}_{4}$ \\
\hline Hexahydro-difenidol (1a) & 130 & 16 & 160 & 79 \\
Hexahydro-difenidol/methiodide (4a) & 130 & 160 & 400 & 250 \\
$\begin{array}{l}\text { p-Fluoro-hexahydro-difenidol (8a) } \\
\text { p-Fluoro-hexahydro-difenidol/ }\end{array}$ & 100 & 13 & - & 130 \\
methiodide (9a) & 130 & 80 & & 100 \\
\hline
\end{tabular}


'omers of la and $8 \mathrm{a}$ was increased two- to threefold by $\mathrm{N}$-methylation $(\rightarrow 4 \mathrm{a}$ and $9 \mathrm{a})$. In heart $\left(\mathrm{M}_{2}\right.$ sites). the affinities of the (R)-enantiomers of $1 \mathrm{a}$ and $8 \mathrm{a}$ were increased 10 - to 20 -fold by $\mathrm{N}$-methylation $(\rightarrow 4 \mathrm{a}$ and 9a) but the affinities of the (S)-enantiomers were almost unchanged. In pancreas $\left(M_{3}\right.$ sites), thc affinities of (R)-hexahydro-difenidol ((R)-1a) and its methiodide ((R)-4a) were identical but $N$-methylation decreased the affinity of the (S)-enantiomers ((S)-1a $\rightarrow(s)-4 a)$. In striatum ( $\mathrm{M}_{4}$ sites), the affinities of (R)-1a. (R)-8a and (S)-8a were increased two- to fourfold by $\mathrm{N}$-methylation, whereas the affinity of (S)-1a was unchanged.

p-Fluoro substitution of the enantiomers of hexahydro-difenidol (1a) and its methiodide (4a) changed only slightly (if at all) their affinities for $\mathrm{M}_{1}, \mathrm{M}_{2}$ and $M_{4}$ sites (table 1). This effect did not depend on the absolute configuration of the compounds.

\section{Discussion}

The present study investigated the effects of chang. ing the size of the cyclic amino group (compounds 2 and 3). introducing substituents in the phenyl ring (compounds $5-7,8 \mathrm{~b}$ ) and $\mathrm{N}$-methylation (compounds $4 \mathrm{~b}$ aild $9 \mathrm{~b}$ ) of hexahydro-sila-difenidol (1b) as well as the effects of replacing the central silicon atom of compounds $1 \mathrm{~b}, 4 \mathrm{~b}, 8 \mathrm{~b}$ and $9 \mathrm{~b}$ by a carbon atom (compounds $1 \mathrm{a}, 4 \mathrm{a}, 8 \mathrm{a}$ and $9 \mathrm{a}$ ) on muscarinic binding affinity and receptor selectivity. All the compounds tested in this work possess a center of chirality (central silicon or carbon) and therefore exist in two enantiomers. We had indications that silanols $\left(\mathrm{R}_{3} \mathrm{SiOH}\right)$ may racemize in aqueous solution (Tacke et al., 1987). Thus compounds $1 \mathrm{~b}, 2-7,8 \mathrm{~b}, 4 \mathrm{~b}$ and $9 \mathrm{~b}$ were studied as racemates. In contrast, the carbon compounds $1 \mathrm{a}, 4 \mathrm{a}, 8 \mathrm{a}$ and $9 \mathrm{a}$ (carbinols, $\mathrm{R}_{3} \mathrm{C} \mathrm{OH}$ ) exist in configurationally stable enantiomers. We took advantage of this by investigating the binding properties of the individual enantiomers of these compounds at muscarinic receptor subtypes.

\subsection{Binding propeities of p-fluoro-hexahydro-sila-difen- idol}

The binding affinities ( $\mathrm{pK}$, values, table 1) obtained with most of the hexahydro-sila-difenidol analogues correspond closely to their antimuscarinic potencies ( $\mathrm{pA}$ values) determined in functional experiments at $M_{1}, M_{2}$ and $M_{3}$ receptors (Lambrecht et al., 1988; 1989a,b; Eltze et al., 1988). We were therefore particularly interested in the binding properties of p-fluorohexahydro-sila-difenidol ( $8 \mathrm{~b}$ ) which bebaved in functional experiments as a selective $M_{3}$ antagonist $\left(M_{3}>\right.$
$M_{1}>M_{2}$ ) (Lambrecht et al.. 1988. 1989a,b; Eglen et al., 1989: Whiting et al., 1989). In this study we did not find $M_{1}$ muscarinic binding sites with a low affinity for p-fluoro-hexahydro-sila-difenidol (8b) in human neuroblastoma NB-OK 1 cells (labelled by [ ${ }^{7}$ H]NMS; table 1) or in rat brain cortex, hippocampus and striatum homogenates labelled by $\left[{ }^{3} \mathrm{H}\right]$ pirenzepine (data not shown). In contrast, the $\mathrm{pK}$, values of $\mathrm{p}$-fluoro-hexahydro-siladifenidol (8b) obtained at cardiac $M_{2}(6.5)$ and pancreas $M_{3}$ sites (7.8) were in reasonable agreement with the $\mathrm{pA}_{2}$ values observed in pharmacological studies using isolated guinea-pig atria $\left(\mathrm{M}_{2} ; 6.0\right)$ and ileum $\left(\mathrm{M}_{3}\right.$; 7.8) preparations (Lambrecht et al., 1988, 1989b).

In fact, compound $8 \mathrm{~b}$ showed a markedly higher affinity for $\mathrm{M}_{1}$ binding sites in this study $\left(\mathrm{pK}_{i}=7.8\right.$; table 1 ) as compared to functional $M_{1}$ receptors in rat ganglia $\left(\mathrm{pA}_{2}=7.2\right)$, rabbit vas deferens $\left(\mathrm{pA}_{2}=6.7\right)$ (Lambrecht et al., 1988, 1989b) or canine femoral (pA $=7.1$ ) and saphenous vein $\left(\mathrm{pA}_{2}=7.1\right)$ (Eglen et al., 1989: Whiting et al., 1989). Our results also contrast with the low affinity of $8 \mathrm{~b}$ in binding studies using $\left[{ }^{3} \mathrm{H}\right]$ telenzepine-labelled calf superior cervical ganglia $M_{1}$ receptors (Lambrecht et al., 1989a). We do not have at present a satisfactory explanation for these differences. Since it was well known that the binding of antagonists to muscarinic $M_{1}$ receptors is sensitive to the ionic conditions in the incubation medium (Freedman et al., 1988) we : peated our binding experiments at $M_{1}$ receptors in NB OK 1 cells with p-fluoro-hexahydro-sila-difenidol (8b) using the Tris buffer which was used by Lambrecht et al. (1989a and unpublished data) in binding studies at $M_{1}$ receptors of calf superior cervical ganglia. Under these ionic conditions we again found only high-affinity binding for compound 8 b (data not shown) in NB-OK 1 cells. An alternative explanation, that $M_{1}$ receptors in ganglia and rabbit vas deferens are different from $M_{1}$ receptors in rat brain and human NB-OK 1 cells seems also unlikely. All the other compounds investigated in this and other studies including the closely related compounds $8 \mathrm{a}$ and $9 \mathrm{~b}$ ) bad similar affinities for the $M_{1}$ binding sites of rat brain and human NB-OK 1 cells and for the functional (rabbit vas deferens and ganglia) $M_{3}$ receptors (Waelbroeck et al., 1989a; Lambrecht et al., 1988; 1989a,b; Eltze et al., 1988; Feifel et al., 1990; Lambrecht et al., unpublished results).

\subsection{Structure-selectivity relatioiships}

When comparing the structure-binding relationship of hexahydro-siia-difenidol anaiogues to muscarinic receptor subtypes, these muscarinic antagonists showed some quantitative and qualitative differences in receptor selectivity profiles (table 1 ). 
The influence of the ring size of the cyclic amino group on binding affinity and selectivity can be demonstrated by comparison of compounds $1 b, 2$ and 3 . It is obvious from the data in table 1 that lice affinity to the four muscarinic receptor subtypes depends on the structure of the heterocyclic ring and varies up to fivefold. Compound 2, possessing a pyrrolidino ring shows nearly the same affinity for the four muscarinic receptors as the parent compound hexahydro-sila-difenidol (1b). In contrast, ring extension to the hexamethyleneimino analogue 3 results in a deciease in affinity, this decrease being greatest at $M_{3}$ receptors. However, the influence of the size of the cyclic amino group on receptor selectivity is moderate as compounds 2 and 3 showed about the same selectivity pattern as the parent compound $1 \mathrm{~b}$ : $M_{1} \approx M_{3} \approx M_{4}>M_{2}$.

N-Methylation of (R)-hexahydro-difenidol ((R)-1a $\rightarrow(R)-4 a)$, hexahydro-sila-difenidol $(1 b \rightarrow 4 b),(R)-p$ fluoro-hexahydro-difenidol $[(R)-8 a \rightarrow(R)-9 a]$ and $p-f l u-$ oro-hexahydro-sila-difenidol $(8 b \rightarrow 9 b)$ increased the affinity for $M_{1}, M_{2}$ and $M_{4}$ receptors up to 20-fold, this increase being consistently greatest at $M_{2}$ receptors. In contrast, the affinity of compound (R)-1a for $M_{3}$ receptors in pancreas was not changed by $\mathrm{N}$-methylation, and that of $1 \mathrm{~b}$ was increased only 2.5 -fold. Thus, $\mathrm{N}$ methylation of the tertiary amines (R)-1a, 1b, (R)-8a and $8 \mathrm{~b}$ changed the receptor selectivity pattern from $M_{1} \approx M_{3} \approx M_{4}>M_{2}$ to $M_{1} \geqslant M_{4}>M_{3} \approx M_{2}$ receptors, abolishing the selectivity between $M_{2}$ and $M_{3}$ receptors. It is interesting to note that the binding affinities of (S)-1a and (S)-8a were only slightly affected by $\mathrm{N}$-methylation at all muscarinic receptor subtypes. It is generally assumed that tertiary antimuscarinic agents interact in their protonated form with these receptors (Barlow and Chan, 1982; Asselin et al., 1983). N-Methylation probably does not change the overall charge of the cationic head of the compounds studied: steric factors due to the presence of an additional N-methyl group may play an important role in the interaction of the quaternary compounds $4 a, 4 b, 9 a$ and $9 b$ with muscarinic receptors.

We also investigated in this study the effe:s of substitution of the phenyl ring in the para and crtho positions. The derivatives of hexahycro-sila-difenidol and hexahydro-difenidol and of their methiodides tested had equal or lower affinities than the parent compounds (table 1) at the four subtypes. The affinity decreases might be due to steric hindrance, modification of the electron distribution of the molecules, or both. It is interesting in this respect that the affinities of compounds (R)-1a/(R)-8a, (S)-1a/(S)-8a, 1b/8b, (R)$4 a /(R)=9 a$ and $(S)-4 a /(S)-9 a$ were very similar, regardless of the receptor subtype $\left(M_{1}, M_{2}, M_{4}\right)$ studied and of the absolute drug configuration. In contrast, $9 b$ had a two- to threefold lower affinity than $4 b$ for $M_{1}$, $M_{2}$ and $M_{4}$ receptors. This supports the view that the drug position in the muscarinic binding site is adapted depending on the actual drug structure, and is not necessarily identical when comparing tertiary and quaternary analogues or carbon/silicon bioisosters.

It is notew orthy that the affinity decrease due 10 p-chloro substitution ( $1 \mathrm{~b} \rightarrow 7$ ) was greatest at $M_{2}$ receptors. Thus, the p-chloro analogue 7 shows a greater selectivity (30-fold) for $M_{3} / M_{3} / M_{4}$ receptors over $M_{2}$ receptors than the parent compound $1 \mathrm{~b}$. o-Methoxyhexahydro-sila-difenidol (6) presented a unique selectivity profile. It recognized preferentially the $M_{4}$ receptors, had an intermediate affinity for $M_{1}$ and $M_{3}$ receptors and lowest affinity for $M_{2}$ receptors.

In general, the ( $R$ )-enantiomers of compounds $1 \mathrm{a} .4 \mathrm{a}$. $8 \mathrm{a}$ and $9 \mathrm{a}$ showed higher binding affinities (up to 398fold) for the four muscarinic receptor subtypes than the corresponding (S)-configurated isomers (table 1). How:ever, this stereoselectivity was not the same for all receptor subtypes. The stereoselectivity ratios (table 2) for the tertiary compounds hexahydro-difenidol (1a) and its p-fluoro analogue 8 a consistently show the same order: $M_{1} \approx M_{3} \approx M_{4}>M_{2}$. This implies that the stereochemical requirements of the muscarinic $M_{2}$ receptors are less stringent than that of the other subtypes for the enantiomers of $\mathrm{la}$ and $8 \mathrm{a}$. Similar results have been obtained with the enantiomers of other tertiary antimuscarinics such as trihexiphenidyl, hexbutinol, telenzepine or biperiden (for a recent review, see Lambrecht et al., 1989a; Waelbroeck et al, 1989b). The stereoselectivity ratios for the two quaternary compounds $4 a$ and $9 a$ at $M_{2}$ receptors are very similar to those of the other subtypes. This is mainly dise to the stereoselective effect of $\mathrm{N}$-methylation on the affinity of the (R)-nantiomers of compounds ia and $8 \mathrm{a}$.

In conclusion, this report describes structure-activity relationships (including stereochemical aspects) of muscarinic antagonists related to bexahydro-sila-difenidol (1b). All compounds behaved as competitive inhibitors of $\left.{ }^{3} \mathrm{H}\right]-\mathrm{N}$-methylscopolamine binding at $M_{1}$ receptors in human neuroblastoma NB-OK 1 cells. $M_{2}$ receptors in rat heart as well as $M_{3}$ and $M_{4}$ receptors in rat pancreas and striatum, respectively. The binding affinity and receptor selectivity in this series of compounds was fcund to be controlled by the structure of the cyclic amino (ammonium) group, the substitution pattern of the phenyl moiety and the absolute configuration of the chiral carbinols 1a, 4a, 8a and 9a. There was little influence of sila-substitution (carbon/sillicon exchange) on binding affinity of these chiral compounds. In contrast to pharmacological studies using isolated organs such as rabbit vas deferens, rat ganglia and canine veins as weil as to binding studies in calf ganglia, we could not use p-fluoro-hexahydro-sila-difenidol (8b) to discriminate $M_{3}$ from $M_{1}$ binding sites, due to the high affinity of this antimuscarinic agent for $\mathrm{M}_{1}$ binding sites in homogenates of NB-OK 1 cells and rat brain. 


\section{Asknowledgements}

M.W.. J.C. M.T. and J.C. thank the Fund for Medical Scientific Research (Belgium) for grant 3.4571.85. R.T. thanks the Deursche Forschungsgemeinschaft, and G.L.. E.M. and R.T. thank the Fonds der Chemischen Industrie (F.R.G.) for financial support

\section{References}

Akiba. I.. T. Kubo, A. Maeda. H. Bujo. J. Nakaj, M. Mishina and S. Numa. 1988. Primary structure of porcine muscarinic acetylcholine receptor III and antagonist binding studies. FEBS Lett. 235. 257.

Asselin. J. M. Waelbroeck. P. Robberecht. P. De Neef and J. Christophe. 1983. Effect of $\mathrm{pH}$ on binding of agonists and antagonists to rat heart muscarinic receptors. Biochem. J. 216, 11.

Barlow. R.B. and M. Chan, 1982. The effects of pH on the affinity of pirenzepine for muscarinic receptors in the guinea-pig ileum and rat fundus strip. Br. J. Pharmacol. 77. 559.

Bonner. T.1., N.J. Buckley. A.C. Young and M.R. Brann. 1987. Identification of a family of muscarinic acetylcholine receptor genes. Science 237, 527.

Buckley. N.J., T.I. Bonner, C.M. Buckley and M.R. Brann. 1989. Antagonist binding properties of five cloned muscarinic receptors expressed in CHO-KI cells. Mol. Pharmacol. 35. 459

Cheng. Y. and W.H. Prusoff, 1973, Re'ationship between the inhibition constant ( $K$, and the concentration of inhibitor th hich causes 50 per cent inhibition $\left(I_{50}\right)$ of an eazymatic resction. Biochem. Pharmacol. 22, 3099.

Dobrje. F.. J. Wess. G. Lambrecht, M.R. Brann and E. Mutschler. 1990. Antagonisten-bindungsstudien an fünf klonierten Muskanisrezeptor-Subtypen (hmi-hmS) exprimiert in CHO-K1-zellen. Arch. Pharm. 323. 707.

Eglen. R. M.. W.W. Montgomery and C.A. Machado. 1989, Characterization of muscarinic receptors mediating res, jonses in canine femoral vein ard artery in vitro, Trends Pharmacol. Sci. 10 (Suppl.). 107.

Elize, M.. G. Gmelin, J. Wess. C. Strohmann, R. Tacke, E Mutschler and G. LambrechL, 1988, Presynaptic muscarinic reseptors mediating inhibition of neurogenic contractions in rabtit vas deferens are of the ganglionic $\mathrm{M}_{1}$-type European J. Pharmacol. 158. 233.

Feifel. R. M. Wagner-Röder, C. Strohmann, R. Tacke, M. Waelbroeck, J. Christophe, E MutschJer and G. Lambrecht, 1990. Stereoselective inhibition of mustarinic receptor subtypes by the enantiomers of hexahydro-difenidol and acetylenic analogues. E: J. Phamacol. 99.455

Freedman. S.B. M.S. Beer and E.A. Harley. 1988, Muscarinic $M_{1}, M_{2}$ receptor binding Relationship with functional efficacy. European J. Pharmacol. 156, 133.

Giachetti, A., R. Micheletti and E. Montagna, 1986. Cardioselective profile of AF-DX 116. a muscarine $M$ - receptor antagonist. Life Sci. 38. 1663.

Giraldo. E. R. Micheletti. E. Montagna. A. Giachenti. M.A. Vigano. H. Ladinsky and C. Meichiorre. 1988, Binding and functional characterization of the cardioselective inuscarinic antagonist methoctramine, J. Pharmacol Exp. Ther. 244, 10!6.

Hammer, R., C.P. Berrie. N.J.M. Birdsall, A.S V. Burgen and E.C. Hulme, 1980, Pirenzepine distinguishes ber'veen different subclasses of muscarinic receptors, Nature 283, 90 .

Hainmer. R. E. Giraldo, G.B. Schiavi, E Monierini, and H. Ladinsky. 1986. Binding profile of a novel cardioselective musarine receptor antagonist, AF-DX 116, to membrares of perizheral tissues and brain in the rat. Life Sci. 38. 1653.

Lambrecht, G., R. Feifel, B. Forth, C. Strohmann, R. Tacke, ind E
Mutschler. 1988, p-Fluoro-hexahydro-sila-difenidol: the first $M_{2 \beta^{-}}$selective muscarinic antagonist. European J. Pharmacol. 152. 193.

Lambrecht. C... R. Feifel. U. Moser. M. Wagner-Röder. L.K Chov. J. Camus, M Tastenoy, M. Waelbrueck. C. Strohmann, R. Tacke. J.f. Rodrigues de Miranda, J. Chrisiophe and E Musschler. 1989a. Pharmacology of hexahydro-difenidol. hexahydro-sila-difinidol and related selective muscarinic antagonists. Trends Pharmacol. Sci. 10 (Suppl.), 60.

Lambreclht. G. R. Feifel. M. Wagnes-Rider, C. Strohmann. H. Zilch, R. Tacke. M. Waelbroeck. J. Christophe. H. Boddeke and E. Mutschler. $1989 \mathrm{~b}$. Affinity profiles of hexahydro-sia-difenidol analogues at muscarinic receptor subtypes. European J. Pharmacol. 168. 71 .

Lambrecht. G. T.P. Friebe, R. Feifel. N. Retteamayr, M. WaznetRöder, C. Strchmann. R. Tuc̆̉=. and E. Mutschler. 1990, Affinitätsprofile von chiralen analoga des Difer dols and Difenidol-methiodids an Muscariniezeptor-Subtypen, Arch. Pharm. 323, 790.

Lambrecht. G.. E. Mutschler, U. Moser, J. Riotle. M. Wagner, J. Wess. G. Gmelin, R. Tacke and H. Zilch, 1987, Hetergeneity in muscarinic receptors: evidence from pharmacological and electrophysiological studies with selective antagonists, in: International Symposium on Muscarinic Cholinergic Mechanisms. eds. S. Cohen and M. Sokolovsky (Freund Publishing House Ltd., Tel-Aviv) p. 245 .

Lazareno. S. and F.F. Roberts, 1989. Functional and binding studies with muscarinic $\mathrm{M}_{2}$-subtype selective antagonists. Br. J. Pharmacol. 98.309.

Levine, R.R. and N.J.M. Birdsall (eds.). 1989. Subtypes of muscarinic receptors, IV, Trends Pharmacol. Sci. 10 (Suppl.).

Loury, O.H.. N.J. Rosebrough, A.L. Farr and R.J. Randall, 1951, Protein measurement with the Folin phenol reagent. J. Biol. Chem. 193. 265.

Melchiorre, C.. P. Angeli. G. Larriorecht, E. Mutschler, M.T. Picchio and J. Wess, 1987. Antimuscarituc action of methoctramine, a new cardioselective M-2 muscarinir: receptor antagonist, alone and in combination with atropine and gallamine, European 3. Pharmacol. 144. 117.

Michel. A.D. R. Delmendo. E. Stefanich and R.L. Whiting. 1989. Binding characteristics of the muscarinic receptor subtype of the NG108-15 cell line. Naunyn-Schmiedeb. Arch. Pharmacol. 340, 62.

Micheletti. R., E. Montagna and A. Giachetti, 1987, AF-DX 116, a cardioselective n"'sscarinic antagonist. J. Pharmacol. Exp. Ther. 241.628.

Mitchelson. F.. 1988, M'sscarinic receptor differentiation, Pharmacol. Ther. 37, 357 .

Mutschler E. G. Gmelin. U. Moser, J. Wess and G. LambrechL, 1987. Struclure-a tivity relationships of drugs acting selectively at differen: mu arinic receptors. in: Pharmacology, Int. Congr. Series. Vol. 750. eds M.J. Rand and C. Rapes (Elsevier Science Publishers. Amsterdam) p. 67.

Mutschler, E. U. Moser, J. Wess and G. Lambrochi, 1988. New approaches to the subclassification of muscarinic receptors. in: Recent advances in Receptor Chemistry. eds C. Melchiorte and M. Giannella (Elsevier Science Publishers, Amsterdam) p. 195.

Peralia, E. S.. A. Ashkenazi, J.W. Winslow. D.H. Smith, J. Ramachandran and D.J. Capon. 1987. Distinct primary structures, ligand-binding properties and tissue-specitic expression of four human muscarinic acetylcholine receptors. EMBO J. 6, 3923.

Richardson. A and A. Humrich, 1984. A microcomputer program for the analysis of iddioligand binding curves and other dose-response data. Trends Pharmacol. Sci. 5, A7.

Sarge. S., S. Bauerecker and H.K. Cammenga, 1988, Calorimetric determination of purity by stimulation of dse curves. Thermochim. Acta 129. 309. 
Sarge. S. and H.K. Cammenga. 1985, Calibration of differential sca.ning calorimeters using $\Delta H-/ T$ - and $C_{p}$-standards: Extended application to two instruments, Thermochim. Acta 94, 17.

Tacke, R, H. Linoh, L. Emst, U. Moser, E. Mutschler, S. Sarge, H.K. Cammenga and G. Lambrecht, 1987. Preparalion and properties of the enantiomers of the antimuscarinic agents sila-procyclidine and sila-tricyclamol iodide: optically active silanols with silicon as the ceritre of chirality. Chem. Ber. 120, 1229.

Tacke, R., H. Linoh, H. Zilch. J. Wess, U. Moser, E. Mutschler and G. Lambrech1. 1985. Synthesis and properties of the selective antimuscarinic agent cyclohexylphenyl(3-piperidinopropy!)silanol. Liebigs Ann. Chem. 2223.

Tacke, R., C. Strohmann, S. Sarge, H.K. Cammenga, D. Schomburg E Mutschler and G. Lambrecht, 1989, Preparation and properties of the enantiomers of the selective antimuscarinic agent 1 cyclohexyl-1-phenvi-4-piperidino-1-butanol (hexahydro-difenidol). Liebigs Ann. Chem. 137.

Waelbroeck, M., J. Camus, 3. Winand and J. Christophe. 1987a. Different antagonist binding properties of rat pancreatic and cardiac muscarinic receptors, Life Sci. 41, 2235

Waelbroeck. M., J. Camus. M. Tastenoy and J. Christophe. 1988. 80 of muscarinic receptors expressed by the NB-OK 1 human neuroblastoma cell line show high affinity for pirenzepine and are comparable to rat hippocampus $M_{1}$ receptors. FEBS Lett. 226. 287

Waelbroock. M., M. Gillard, P. Robberecht and J. Christophe. 1987b.
Muscarinic receptor heterozeneity in the rat central servous system. I. Birding of four selective antagonists to tintee muscaninic receplor subclasses: a comparison with $\mathbf{M}_{\text {; }}$ cardiac muscarinio receplors of the C uppe, Mol. Pharmaco!. 32. 91.

Waelbroeck. M, M. Tastency, J. Camus and J Christophe. 1990. Bindmg of selective antagonists to four muscartic recpior $\left(M_{1}\right.$ th $M_{4}$ ) in rat foretran. Mol. Prarmacol. 38. 267.

Watbroeck. M.. M. Tastenoy. J. Camus. J. Chrstoghe, C. Strohmann. H. Linoh. H. Zilch. R. Tacke. E. Mutschles and $G$ Lambrecht, 1989a. Binding and functional properties of antimuscarinics of the hexacjelium/sila-hexocyclium and hexabydrodiphenidol, hexahydro-sila-diphenidol type to muscarinic receptor sublypes. Br. J. Pharmacol 98. 197.

Waelk:oeck. M. M. Tastenoy, J. Camus, R. Feifel. E Muischier. C. Strohmann R. Tacke, G. Lambrechn and J. Christophe. 1959h. Stereoselectivity of the interaction of minscarinic antagonists with their receptors. Trends Pharmacol. Sci. 10 (Suppl.). 65.

Wess. J.. G. Lambrecht. E. Mutschler. M.R. Brann and F. Döna. 1990. Selectivity profile of the novel muscariric antagonis! LiH-AH 37 deterrrined by the use of cloned receptors and isolated tissue preparations. Br. J. Pharnacol., in press.

Whuting. R.L.. R.M. Eglen. W.W. Mfontgomery ard C.A. Mathado. 1989. Interaction of p-flumohex hydrosiadifeaidol ( $p F H$ HSiD) al muscarinic receptor subivpes in vitro. Trends Pharmacol. Sa. 10 (Suppl.). 105. 